\title{
Rozpoznanie warunków gruntowych wybranego odcinka przekopu kolejowego jako podstawa projektowania prac geoinżynieryjnych w celu poprawy parametrów geotechnicznych
}

\author{
Jan Ziaja $^{1}$ (D), Cezary Cały ${ }^{2}$, Angelika Druzgała ${ }^{3}$ (D), \\ Justyna Adamczyk ${ }^{4}$ (D), Przemysław Toczek ${ }^{5}$ (D) \\ 1 AGH Akademia Górniczo-Hutnicza, Wydział Wiertnictwa, Nafty i Gazu, Kraków \\ 2 PKP PLK S.A., Dział Technologii i Laboratorium dla Regionu Śląskiego \\ 3 AGH Akademia Górniczo-Hutnicza, Wydział Wiertnictwa, Nafty i Gazu, Kraków \\ 4 AGH Akademia Górniczo-Hutnicza, Wydział Inżynierii Lądowej i Gospodarki Zasobami, \\ Kraków \\ 5 AGH Akademia Górniczo-Hutnicza, Wydział Wiertnictwa, Nafty i Gazu, Kraków
}

\begin{abstract}
Streszczenie: W artykule dokonano podziału metod inżynierskich, które mogą być zastosowane w celu poprawy parametrów geotechnicznych gruntów w miejscu zaistnienia ich dysfunkcji powodujących utratę stateczności, nośności itp. W pracy wskazano badania geoinżynierskie niezbędne w analizie warunków geotechnicznych. Omówiono analizę stateczności opisywanego odcinka linii kolejowej przebiegającej przez obszar Karpat Zachodnich. Przedstawiono wyniki badań terenowych i laboratoryjnych. Brak stateczności analizowanego odcinka skutkuje koniecznościa przeprowadzenia geoinżynierskich prac wzmacniających, mających na celu poprawę parametrów geotechnicznych oraz zabezpieczenie skarpy przed osuwaniem.
\end{abstract}

Słowa kluczowe: stabilizacja skarp, metody geoinżynieryjne, sonda CPTU, analiza stateczności górotworu

\section{INVESTIGATION OF SOIL CONDITIONS}

IN A SELECTED SECTION OF A RAILWAY CUT

AS A BASIS FOR DESIGNING GEOENGINEERING WORKS

TO IMPROVE THEIR GEOTECHNICAL PARAMETERS

\begin{abstract}
The paper divides engineering methods that can be applied to improve geotechnical parameters of soils at the site of their dysfunctions causing loss of stability, bearing capacity, etc. The paper identifies geo-engineering studies necessary to analyse geotechnical conditions. Analyses of stability of the described railway line section running through area of the Western Carpathians are discussed. Results of field and laboratory tests are presented. The lack of stability of the analysed section results in the need to carry out geo-engineering reinforcement works to improve the geotechnical parameters and to protect the slope against landslides.
\end{abstract}

Keywords: slopes stabilization methods, geoengineering methods, CPTU probe, rock mass stability analysis

https://doi.org/10.7494/978-83-66727-48-9_14 


\section{Wprowadzenie}

Stopień konsolidacji, wartość naprężenia oraz nasycenie wodą podłoża gruntowego można zaliczyć do najistotniejszych czynników wpływających na jego nośność i stateczność. Sposobem pozwalającym na realizację obiektów budowlanych w podłożu gruntowym charakteryzującym się nieodpowiednimi właściwościami geomechanicznymi jest modyfikacja parametrów fizyczno-mechanicznych podłoża gruntowego w zamierzonym zakresie nowymi metodami (Gonet i Stryczek 2020).

Wznoszenie oraz późniejsze utrzymanie budowli inżynierskich, obiektów ciągów komunikacyjnych, hydrotechnicznych i innych stwarza problemy, które należy bezsprzecznie rozwiązać w trakcie realizacji prac, w celu poprawy parametrów fizycznych i mechanicznych gruntu - jeśli istnieje taka potrzeba - oraz zamiany parametrów fizycznych i mechanicznych podłoża gruntowego na takie, które pozwolą na poprawę i utrzymanie odpowiednich warunków geoinżynieryjnych oraz geotechnicznych w zagrożonych terenach.

Występujące problemy powodowane są głównie skomplikowanymi warunkami geologicznymi, hydrogeologicznymi czy geomechanicznymi, ale również błędami w prowadzonych wcześniej pracach inżynierskich. Kompleksowa analiza warunków geologicznych oraz ograniczeń technicznych i technologicznych w miejscu wykonywania prac inżynieryjnych pozwala na modyfikację właściwości fizyczno-mechanicznych podłoża pod obiektami budowlano-inżynieryjnymi (Stryczek 1999, Pisarczyk 2005, Gonet i Stryczek 2020).

\section{Metody geoinżynieryjne}

Zakres możliwych do wykonania prac geoinżynieryjnych jest ściśle zależny od uwarunkowań geologicznych oraz właściwości fizyczno-mechanicznych gruntów i skał (Gonet i Stryczek 2020) mających wpływ na planowane, wykonane i użytkowane w rozpatrywanym rejonie obiekty techniczne. Na rysunku 1 wskazano dziedziny, w których stosowane są metody geoinżynieryjne.

Wzmacnianie podłoża gruntowego jest ważnym etapem przy wykonywaniu różnych obiektów budowlanych w razie niewystarczającej nośności podłoża. Metody modyfikacji podłoża gruntowego najogólniej można podzielić na metody mechaniczne, chemiczne oraz fizyczno-chemiczne. Innym podziałem metod stabilizacji i zabezpieczeń stoków jest wyróżnienie zabezpieczeń naturalnych, konstrukcyjnych oraz syntetycznych (Kowacki 2015). Stateczność zboczy, nasypów i wykopów jest jednym z najważniejszych zagadnień przy projektowaniu i wykonywaniu obiektów budowlano-inżynieryjnych. 


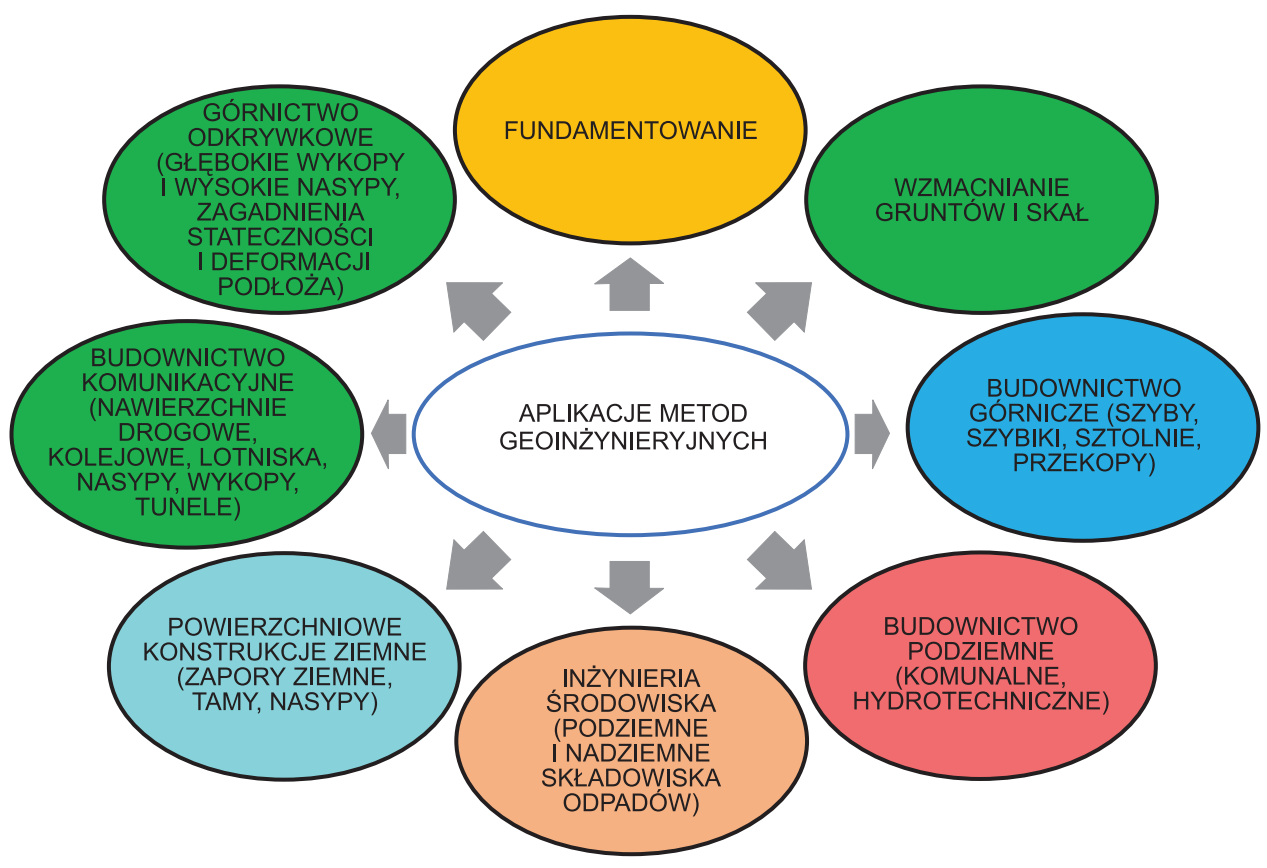

Rys. 1. Zakres zastosowań metod geoinżynieryjnych

Źródło: opracowanie na podstawie Gonet i Stryczek (2020)

Zgodnie z klasyfikacją aplikacji metod geoinżynieryjnych wykonane prace służyły wzmocnieniu gruntu w celu stabilizacji osuwiska wzdłuż pobocznicy nawierzchni przekopu kolejowego (rys. 1 - kolor zielony).

Podczas wykonywania, rewitalizacji oraz renowacji wzdłuż szlaków komunikacyjnych często występują są osuwiska. Problem osuwisk występuje w przypadku braku możliwości ich ominięcia, a także w przypadku renowacji obiektów infrastruktury, którym one zagrażają (Głażewski i in. 2010, Kowacki 2019). Stąd też bardzo ważne jest prognozowanie występowania potencjalnych zagrożeń (Wysokiński 2011). Zabezpieczanie skarp i osuwisk jest tematem cały czas aktualnym zarówno ze względu na związane $\mathrm{z}$ nimi zagrożenia dla stateczności budowli, jak i z uwagi na rozwój metod naukowych umożliwiających zapobieganie tego typu negatywnym zjawiskom (Maca 2020). Stabilizacje osuwisk komunikacyjnych metodami konstrukcyjnymi zaprezentowali m.in. Furtak i Sala (2005), a metodami naturalnymi oraz geosyntetykami - m.in. Łęcki i Różański (2015) oraz Bzówka (2015).

Aby dobrać odpowiednią metodę modyfikacji parametrów fizyczno-mechanicznych, należy wykonać analizę warunków panujących przed przystąpieniem do prac wykonawczych. Jedną z najczęściej stosowanych metod rozpoznania podłoża gruntowego jest sondowanie statyczne CPTU (Cone Penetration Test with Pore Pressure Measurement) (Bagińska 2012, Czado i Pietras 2012). Powstanie i rozwój tego typu sondowania datują 
się na początek lat 90. (U.S. Department of the Interior Bureau of Reclamation 2001). Wyniki sondowań zapewniają wielorakie możliwości interpretacji danych, w zależności od celu ich wykorzystania, np. podczas badań osuwisk (Bednarczyk 2004) czy też w procesie projektowania fundamentów, w tym nośności pali (Czado i Pietras 2012, Bagińska i Sacha 2016, Eslami i in. 2019). Rozpoznanie podłoża gruntowego może być wykonane również za pomocą sondy SCPTU (statycznej sondy CPTU wyposażonej w moduł sejsmiczny) (Jędrysiak i Bagińska 2010).

W artykule przedstawiono analizę przeprowadzoną na podstawie sondowań CPTU (tab. 1), wykonanych wzdłuż osuwiska skarpy przekopu kolejowego (rys. 2) w punktach $A_{i}, B_{i}$ i $T_{i}$, dla przekroju w poprzek analizowanej skarpy, gdzie stwierdzono przemieszczanie mas gruntowych po powierzchni poślizgu w wyniku przekroczenia wytrzymałości ośrodka gruntowego na ścinanie. Głębokość, prędkość i rodzaj przemieszczeń mogą być bardzo zróżnicowane, a od ich wartości zależy powstanie charakterystycznych form morfologicznych. Formy, które stwierdzono w osuwisku, powstały jako efekt procesu sufozji (Stryczek i in. 2008), czyli na skutek wypłukiwania cząstek gruntu przez wody gruntowe, w ośrodku gruntowym o niskim stopniu plastyczności (piaski pylaste, pyły piaszczyste). W analizowanym przypadku formy osuwiskowe związane są bezpośrednio z ukształtowaniem morfologicznym i budową geologiczną, a ich potencjalne występowanie na skarpach i zboczach jest wynikiem działania siły ciężkości. Formy te powstały po przekroczeniu równowagi pomiędzy składowymi naprężenia ścinającego i oporem gruntu na ścianie.

\section{Analiza stateczności jako podstawa projektowania prac geoinżynieryjnych na potrzeby zabezpieczenia skarp}

Wykonano analizę stateczności ogólnej skarp przekopu kolejowego na odcinkach występowania ich dysfunkcji. W celu znalezienia odpowiedniego rozwiązania zapewniającego stateczność skarpy należy określić czynniki ją destabilizujące. Utrata stateczności pojawia się, gdy naprężenia ścinające przekraczają wytrzymałość gruntu na ścinanie. Może być to spowodowane pojawieniem się dodatkowych siły zsuwających, zmianą warunków gruntowo-wodnych bądź działaniem czynników erozyjnych zmniejszających wytrzymałość gruntu. Często jest to kombinacja powyższych czynników - w takim przypadku zaprojektowanie zabezpieczenia jest procesem złożonym.

Przystępując do prac geotechnicznych, w pierwszej kolejności należy wziąć pod uwagę morfologię oraz hydrografię terenu prac. Dokładne rozeznanie terenu badań pozwala na przygotowanie koniecznych prac geotechnicznych, które umożliwią przeprowadzenie poprawnej analizy stateczności skarp, nasypów, przekopów etc. Zgodnie z podziałem fizyczno-geograficznym obszar, na którym przeprowadzone zostały prace, leży w Karpatach Zachodnich. Geologicznie leży na terenie płaszczowiny śląskiej. Jest 
to jednocześnie wododział między dorzeczami Wisły i Odry. Szczegółowa analiza przebiegu linii kolejowej na mapie geologicznej Polski, arkusz Cieszyn, wskazuje, że leży ona na podłożu zbudowanym z twardych łupków kredowych z wkładkami wapieni i margli cienkoławicowych płaszczowiny śląskiej. Na niektórych odcinkach na powierzchni zalegają holoceńskie iły i gliny oraz plejstoceńskie lessy i mułki lessopodobne, które stanowią słabą bazę dla posadowienia podtorza kolejowego. Analiza osuwisk w jednostkach rejestrowych Państwowego Instytutu Geologicznego (SOPO PIG-PIB, listopad 2021) nie wykazała ich występowania w analizowanym obszarze. Prace rozpoczęto od wizji lokalnej, która pozwoliła na dokładną analizę warunków geotechnicznych rejonu prowadzenia prac pod względem morfologii, hydrografii, budowy geologicznej i ewentualnych dysfunkcji, jakie mogą występować na danym terenie, a które będą bezpośrednio wpływać na prace projektowo-wykonawcze.

W analizowanych skarpach przekopu kolejowego problemem jest występowanie uplastycznionej warstwy gruntu pylastego, w którym w wyniku ścięcia wytworzyła się płaszczyzna poślizgu. Stosunkowo strome ukształtowanie skarp nie zapewnia wystarczającej stabilizacji, sprzyjając powierzchniowym osunięciom gruntu. Zgodnie z wytycznymi normy (PN-EN 1997-1:2008/Ap2:2010, 2010) wartości wskaźnika stateczności zostały oszacowane na podstawie parametrów obliczeniowych, tj. parametrów o $25 \%$ niższych od oznaczonych w badaniach terenowych lub laboratoryjnych. Wyniki są zatem odpowiednio zaniżone.

Analiza stateczności została wykonana dla przekrojów w poprzek analizowanej skarpy w odległości co 50 m (rys. 2) zgodnie z poniższym zestawieniem:

- przekrój w km 33+250,

- przekrój w km 33+300,

- przekrój w km 33+350,

- przekrój w km 33+400.

W tabeli 1 wskazano głębokości wykonanych sondowań CPTU oraz otworów w punktach $A_{i}, B_{i}$ i $T_{i}$ (rys. 2) dla przekroju w kilometrażu 33+350 skarpy rewitalizowanego przekopu kolejowego.

Podczas badania CPTU rejestrowano z rozdzielczością wynoszącą $1 \mathrm{~cm}$ głębokości takie parametry, jak:

- opór pod stożkiem sondy $q_{c}[\mathrm{MPa}] \mathrm{w}$ zakresie 0-100 MPa z rozdzielczością $0,01 \mathrm{MPa}$,

- tarcie na tulei ciernej $f_{s}[\mathrm{kPa}] \mathrm{w}$ zakresie $0-3000 \mathrm{kPa}$ z rozdzielczością $0,71 \mathrm{kPa}$,

- ciśnienie porowe w położeniu $u_{2}[\mathrm{kPa}]$ (bezpośrednio za stożkiem, poniżej tulei ciernej) w zakresie 0-3000 kPa z rozdzielczością 0,27 kPa,

- inklinacja stożka $\mathrm{w}$ dwóch wzajemnie do siebie prostopadłych kierunkach $\mathrm{i}_{\mathrm{x}}$ oraz $\mathrm{i}_{\mathrm{y}}\left[^{\circ}\right] \mathrm{w}$ zakresie $\pm 30^{\circ} \mathrm{z}$ rozdzielczością $0,1^{\circ}$,

- prędkość zagłębiania stożka $v[\mathrm{~cm} / \mathrm{s}]$ z rozdzielczością $0,08 \mathrm{~cm} / \mathrm{s}$. 
Tabela 1

Głębokości sondowań statycznych CPTU oraz otworów wykonanych z prawej $\left(\mathrm{A}_{\mathrm{i}}\right)$ i lewej $\left(\mathrm{B}_{\mathrm{i}}\right)$ strony osi oraz $\mathrm{w}$ osi $\left(\mathrm{T}_{\mathrm{i}}\right)$ nawierzchni kolejowej analizowanej skarpy przekopu kolejowego

\begin{tabular}{|c|c|c|c|}
\hline Lp. & $\begin{array}{c}\text { Nr punktu } \\
\text { badawczego }\end{array}$ & $\begin{array}{l}\text { Sonda CPTU } \\
\text { [m p.p.t.] }\end{array}$ & $\begin{array}{c}\text { Otwór } \\
\text { [m p.p.t.] }\end{array}$ \\
\hline 1 & 33+200_T1 & 4,1 & 3,5 \\
\hline 2 & $33+200 \_\mathrm{A}$ & 4,1 & - \\
\hline 3 & 33+200_B & 6,1 & - \\
\hline 4 & 33+250_T1 & 4,1 & 3,5 \\
\hline 5 & 33+250_A & 5,2 & - \\
\hline 6 & 33+250_B & 7,1 & - \\
\hline 7 & 33+300_T1 & 4,1 & 3,5 \\
\hline 8 & 33+300_A & 6,6 & - \\
\hline 9 & 33+300_B & 6,9 & - \\
\hline 10 & 33+350_T1 & 4,1 & 3,5 \\
\hline 11 & 33+350_A & 4,8 & - \\
\hline 12 & 33+350_B & 6,3 & - \\
\hline 13 & 33+400_T1 & 4,1 & 3,5 \\
\hline 14 & 33+400_A & 4,1 & - \\
\hline 15 & 33+400_B & 4,1 & - \\
\hline 16 & 33+450_T1 & 3,6 & 3,5 \\
\hline 17 & 33+450_A & 4,1 & - \\
\hline 18 & 33+450_B & 4,8 & - \\
\hline
\end{tabular}

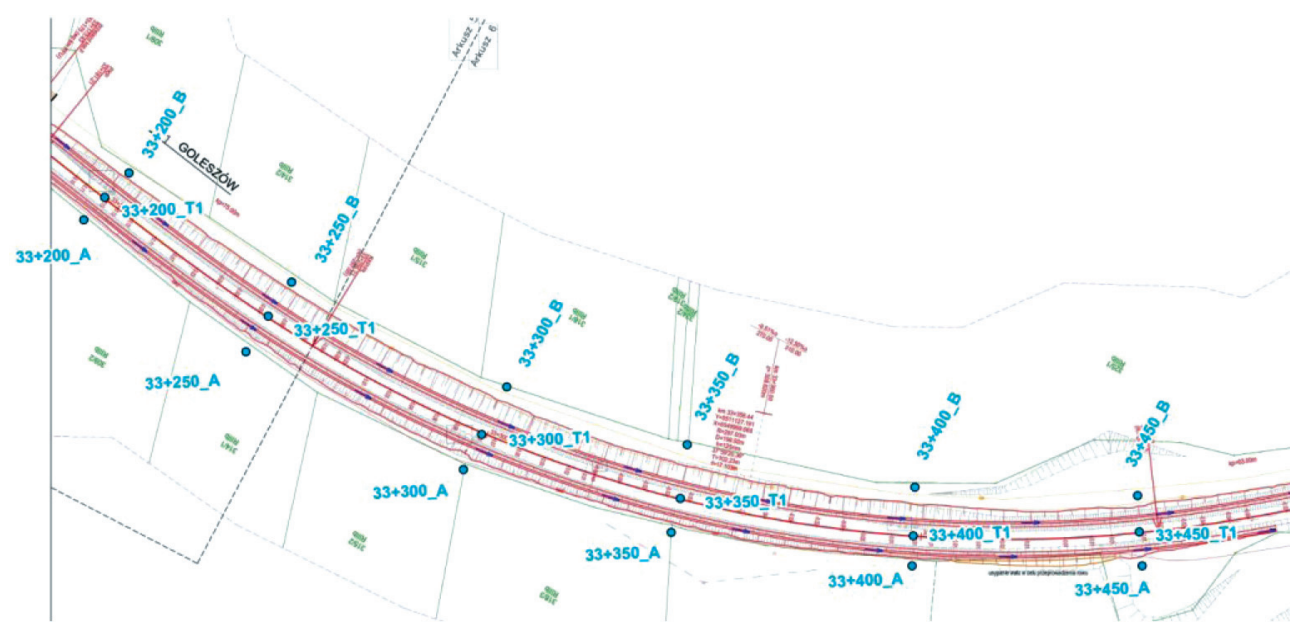

Rys. 2. Charakterystyczne przekroje w poprzek analizowanej skarpy wraz z zaznaczeniem punktów sondowań CPTU 
Do określenia rodzaju gruntu zastosowano diagram Robertsona zmodyfikowany dla gruntów polskich (PN-B-04452:2002, 2002). Na potrzeby wykorzystania ww. diagramu wyznaczane są wartości znormalizowanego oporu stożka $q_{t}$ (z uwzględnieniem ciśnienia porowego $u_{2}$ ) oraz współczynnika tarcia $R_{f}$, zgodnie z normą (PN-EN ISO 22476-1:2013-03, 2013). Ostateczna identyfikacja rodzaju gruntu wykonywana jest manualnie przez interpretatora, z uwzględnieniem informacji o podłożu z równolegle prowadzonych badań, w szczególności wierceń geotechnicznych. Parametry stanu gruntów zostały określone zgodnie z normą (PN-86/B-02480:1994, 1994). Stopień zagęszczenia gruntów niespoistych określono ze wzoru:

$$
I_{D}=0,709 \log q_{c}-0,165
$$

Stopień plastyczności $I_{L}$ gruntów spoistych (lub odpowiadające mu wartości wskaźnika konsystencji $I_{C}$ ) w zależności od zawartości frakcji iłowej w rozpatrywanej warstwie wynosi:

$$
\begin{array}{ll}
I_{L}=0,242-0,427 \log q_{c} & \text { dla } f_{i}>30 \% \\
I_{L}=0,518-0,653 \log q_{c} & \text { dla } f_{i}=10-30 \% \\
I_{L}=0,729-0,736 \log q_{c} & \text { dla } f_{i}<10 \%
\end{array}
$$

Grunty w badanym profilu przydzielono do odpowiedniej grupy na podstawie wcześniejszej interpretacji rodzaju gruntu i wynikającej z niej zawartości frakcji iłowej, zgodnie z diagramem klasyfikacyjnym - tzw. trójkątem Fereta (PN-86/B-02480:1994, 1994).

Kąt tarcia wewnętrznego $\varphi^{\prime}$ gruntów niespoistych wyznaczono na podstawie równania podanego w normie (DIN 4094:1990-12, 2013):

$$
\varphi^{\prime}=23+13,5 \log q_{c}
$$

Przyjęto, że powyższa zależność ma zastosowanie w odniesieniu do gruntów niespoistych, zawierających co najwyżej niewielką domieszkę fakcji drobnej (np. piaski pylaste).

Wytrzymałość na ścinanie gruntów spoistych (drobnoziarnistych) w warunkach bez odpływu $s_{u}$, wyznaczono poniżej:

$$
s_{u}=\frac{q_{c}-\sigma_{v 0}}{N_{k}}
$$

gdzie:

$\sigma_{v 0}$ - pionowe naprężenie całkowite geostatyczne,

$N_{k}$ - współczynnik empiryczny zależny od wskaźnika plastyczności gruntu oszacowany zgodnie z propozycją Szwedzkiego Instytutu Geotechnicznego $\left(N_{k}=13,4+6,6 w_{l}\right)$, przy czym $w_{l}$ to wartość granicy płynności przyjmowana wg tabeli własności typowych gruntów polskich (Wiłun 2013). 
Edometryczne moduły ściśliwości gruntów dla badanego obszaru wyznaczono z normy (PN-B-03020:1981, 1981).

W wyniku przeprowadzonych badań wyróżniono warstwy o horyzontalnym przebiegu. W stropie do głębokości 1,0 m p.p.t. występują pyły, które jednocześnie stanowią powierzchnię uprawną rolniczo. Poniżej do głębokości ok. 3,5 m p.p.t. zalegają warstwy brązowych i szarych glin pylastych w stanie twardoplastycznym, często z przewarstwieniami pyłu (Cały i Kędzierski 2020). Na badanym odcinku (rys. 2) w warstwie glin pylastych zalega w spągu warstwa pyłu o miąższości około $1 \mathrm{~m}$ wraz ze sporą domieszką żwiru drobnoziarnistego. Występują tam także przewarstwienia piaszczyste. Poniżej nawiercono szare gliny pylaste z domieszką żwiru w stanie twardoplastycznym. Duża koncentracja żwiru w stropie nawierconych glin pylastych jest efektem rozmycia erozyjnego. Występowanie gruntów spoistych w stanie plastycznym powoduje powstawanie dysfunkcji, które zagrażają stabilności skarpy i gruntów w okolicach przebiegu linii kolejowej. Domieszka materiału okruchowego i przewarstwień piaszczystych w analizowanych warstwach, sprzyja gromadzeniu się wody w całej rozpatrywanej miąższości, przyczyniając się do rozwoju procesu ich uplastycznienia (Cały i Kędzierski 2020). Szczególnie podatne na uplastycznienie w analizowanym przypadku są pyły ze względu na fakt, że nawet niewielkie ilości wody szybko zmieniają ich stan. $\mathrm{Z}$ tego powodu jest to najsłabsza warstwa, w której powstała krawędź poślizgu (rys. 3).

W obrębie rozpatrywanego przekopu wydzielono sześć warstw geotechnicznych. Przebieg warstw został ustalony na podstawie uśrednionych danych z sondowań CPTU oraz odwiertów geotechnicznych wykonanych w bezpośrednim otoczeniu analizowanego przekroju obliczeniowego. Do warstw geotechnicznych zaliczono grunty tego samego rodzaju i pochodzenia, o zbliżonych wartościach stopnia zagęszczenia (w gruntach sypkich) lub stopnia plastyczności (w gruntach spoistych), dla których przyjęto te same wartości charakterystycznych parametrów fizyczno-mechanicznych. Parametry te zostały wyznaczone na podstawie wyników sondowań CPTU oraz kontrolnych badań laboratoryjnych. Analizy stateczności wykonano dla parametrów obliczeniowych, tzn. parametrów uzyskanych po podzieleniu wartości parametrów charakterystycznych przez współczynnik bezpieczeństwa 1,25 (PN-EN 1997-1:2008/Ap2:2010, 2010). Parametry mechaniczne $\left(\varphi^{\prime}, c^{\prime}\right)$ wierzchnich warstwy skarpy, w których występują wyloty odwodnienia wgłębnego przyległych terenów, zredukowano o współczynnik równy $\gamma_{\text {red }}=1,4$. Parametry warstw geotechnicznych, które zostały wykorzystane do stworzenia modelu obliczeniowego, przedstawiono w tabeli 2 . Podane parametry odnoszą się wyłącznie do rozpatrywanego kilometrażu przekopu i nie należy ich przyjmować jako ogólnych. Analiza stateczności została przeprowadzona metodą Bishopa, dla kołowej powierzchni poślizgu po jej optymalizacji, tzn. wyznaczeniu najbardziej prawdopodobnej powierzchni przebiegu potencjalnych przemieszczeń. 


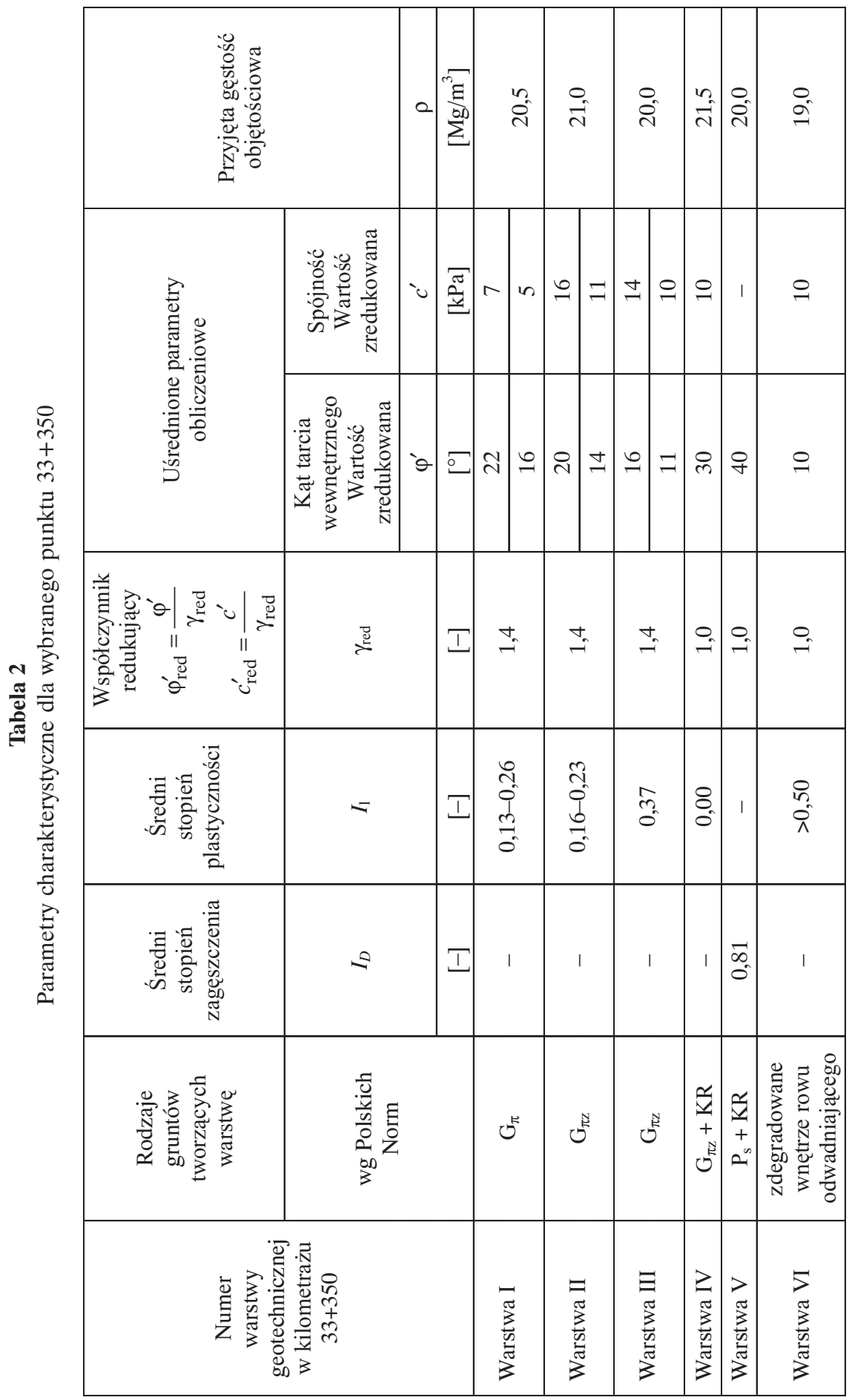




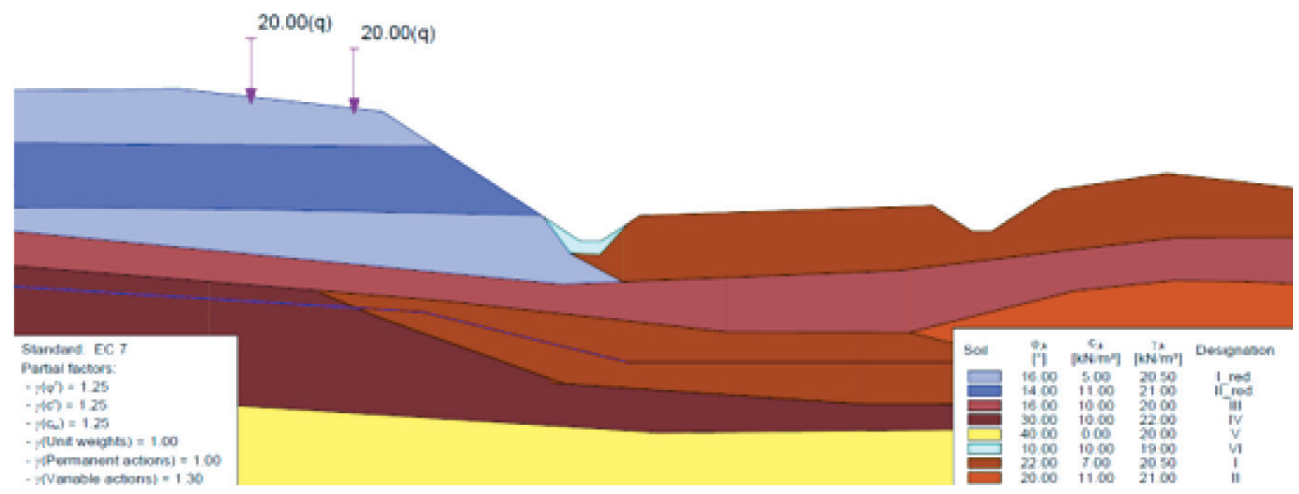

Rys. 3. Przekrój obliczeniowy dla wybranego punktu $33+350$ Źródło: Projekt geotechniczny... (2020)

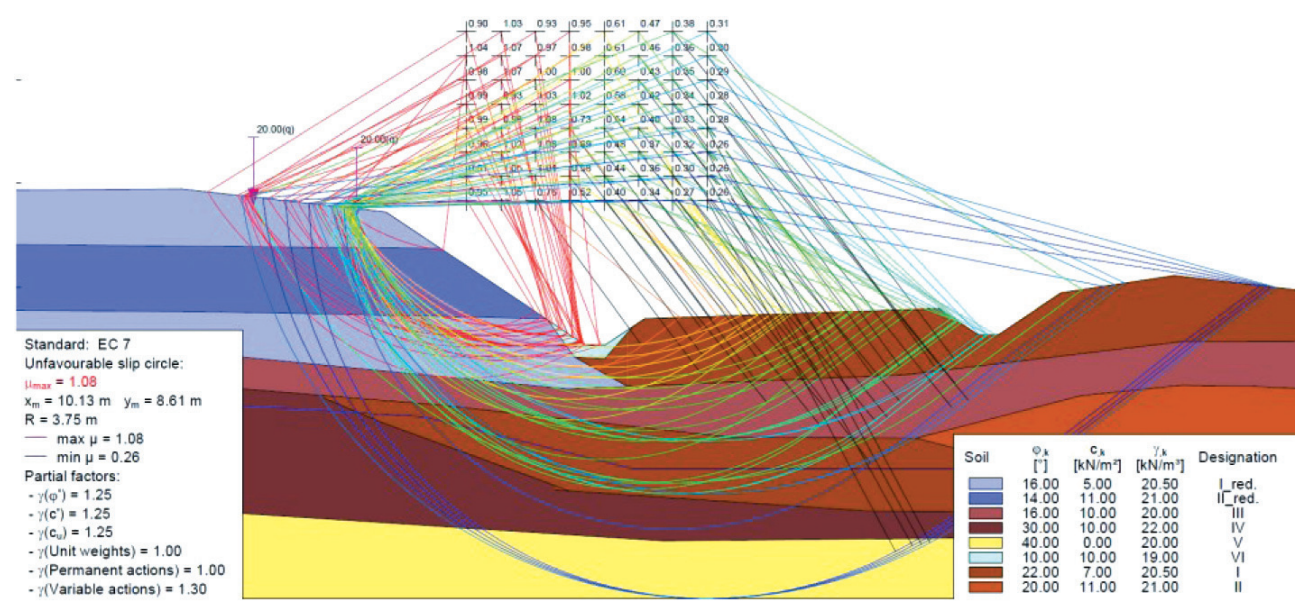

Rys. 4. Widok przekroju obliczeniowego wraz z obliczeniami dla wybranego punktu $33+350$ Źródło: Projekt geotechniczny... (2020)

Na podstawie przeprowadzonej analizy stateczności dla skarpy przekopu kolejowego w kilometrażu 33+350 stwierdzono brak stateczności skarpy ze współczynnikiem stateczności $F_{S}=0,93$. Charakterystyka oraz wykonana analiza stateczności podłoża gruntowego w obrębie przekopu wskazuje na konieczność zaprojektowania prac mających na celu stabilizację skarpy na odcinku 33+350 opisywanego przekopu linii kolejowej.

\section{Wnioski}

Przedstawiony przypadek prac geotechnicznych przeprowadzonych w celu rozpoznania warunków gruntowych dla rozpatrywanego odcinka linii kolejowej wyraźnie wskazuje na brak stateczności skarpy. Wykonane badania polowe i laboratoryjne po- 
zwalają stwierdzić, że dysfunkcja skarpy przekopu kolejowego to bardzo złożone zjawisko, powodowane przez takie czynniki, jak: horyzontalny układ warstw (rys. 3, 4) zalegających konsekwentnie w kierunku przekopu linii kolejowej, warstwowa zmienność parametrów geotechnicznych (warstwy twardych glin przedzielone miękkimi pyłami lub strefą uplastycznioną) oraz niejednorodność gruntów budujących podłoże naturalne, które są bardzo podatne na uplastycznienie. Prawidłowe rozpoznanie warunków gruntowych i wodnych w obrębie analizowanej skarpy pozwala na odpowiednie zaprojektowanie prac. Likwidacja potencjalnego, powodującego uplastycznienie, przesiąkania wód do warstw słabych - będących w szczególności w omawianym przypadku krawędziami poślizgu i miejscem dysfunkcji - to główne zadanie do wykonania w trakcie prac inżynierskich.

\section{Literatura}

Bagińska I., 2012, Analiza oceny rodzaju gruntu ustalonego na podstawie badań CPTU, Geoinżynieria: drogi, mosty, tunele, nr 2, s. 38-45.

Bagińska I., Sacha M., 2016, Przygotowanie wyników sondowania statycznego CPTU a proces projektowania nośności pala wciskanego, Geoinżynieria: drogi, mosty, tunele, nr 3, s. 14-18.

Bednarczyk Z., 2004, Landslide investigations by static sounding with pore pressure measurements (CPTU), ground penetration radar techniques (GPR) and other chosen methods, Polish Geological Institute Special Papers, vol. 15, s. 19-28.

Bzówka J., 2015, Wybrane techniki wzmacniania słabego podtoża gruntowego w budownictwie komunikacyjnym, Inżynieria Morska i Geotechnika, nr 3, s. 416-423.

Cały i Kędzierski, 2020, Ekspertyza geotechniczna dotycząca oceny warunków gruntowo-wodnych linii kolejowej $\mathrm{nr} 190$ od km 33+200 do km 33+500; od km 34+500 do km 34+650 (szlak Goleszów - Cieszyn), PKP PLK S.A. Dział Technologii i Laboratorium dla Regionu Śląskiego, Wrocław [materiały niepublikowane].

Czado B., Pietras J.S., 2012, Comparison of the cone penetration resistance obtained in static and dynamic field tests, AGH Journal of Mining and Geoengineering, vol. 36, no. 1, s. 97-105.

DIN 4094:1990-12, 2013, Baugrund - Erkundung durch Sondierungen [Soil - Exploration by penetration tests], Deutsche Institut für Normung, Berlin.

Eslami A., Moshfeghi S., MolaAbasi H., Eslami M., 2019, Piezocone and Cone Penetration Test (CPT and CPT) Applications in Foundation Engineering, Elsevier, Butterworth-Heinemann.

Furtak K., Sala A., 2005, Stabilizacje osuwisk komunikacyjnych metodami konstrukcyjnymi, Geoinżynieria: drogi, mosty, tunele, nr 3, s. 12-22.

Głażewski M., Nowocień E., Piechowicz K., 2010, Roboty ziemne i rekultywacyjne w budownictwie komunikacyjnym, Wydawnictwa Komunikacji i Łączności, Warszawa.

Gonet A., Stryczek S., 2020, Podstawy geoinżynierii, Wydawnictwa AGH, Kraków. 
Jędrysiak N., Bagińska I., 2010, Rozpoznanie podłoża gruntowego sonda SPCTU, Górnictwo i Geoinżynieria, R. 34, z. 2, s. 341-349.

Kowacki M., 2015, Osuwiska. Cz. 2. Metody stabilizacji i zabezpieczenia terenów osuwiskowych, Nowoczesne Budownictwo Inżynieryjne, nr 1(58), s. 42-47.

Kowacki M., 2019, Stabilizacja skarp i osuwisk, Nowoczesne Budownictwo Inżynieryjne, nr 3(84), s. 88-94.

Łęcki P., Różański M., 2015, Wzmacnianie podłoża gruntowego budowli drogowych, Nowoczesne Budownictwo Inżynieryjne, nr 2(59), s. 46-54.

Maca N., 2020, Praktyczne zasady doboru metod stabilizacji osuwisk, Nowoczesne Budownictwo Inżynieryjne, nr 4(91), s. 64-67.

Pisarczyk S., 2005, Geoinżynieria: metody modyfikacji podłoża gruntowego, Oficyna Wydawnicza Politechniki Warszawskiej, Warszawa.

PN-B-02480:1994, 1994, Grunty budowalne - Określenia, symbole, podziat i opis gruntów, wyd. 2, Polski Komitet Normalizacyjny, Warszawa.

PN-B-03020:1981, 1981, Grunty budowlane - Posadowienie bezpośrednie budowli-Obliczenia statyczne i projektowanie, Polski Komitet Normalizacyjny, Warszawa.

PN-B-04452:2002, 2002, Geotechnika - Badania polowe, Polski Komitet Normalizacyjny, Warszawa.

PN-EN 1997-1:2008/Ap2, 2010, Eurokod 7 - Projektowanie geotechniczne - Część 1: Zasady ogólne, Polski Komitet Normalizacyjny, Warszawa.

PN-EN ISO 22476-1:2013-03, 2013, Rozpoznanie i badania geotechniczne - Badania polowe - Część 1: Badanie sonda statyczna ze stożkiem elektrycznym lub stożkiem piezo-elektrycznym, Polski Komitet Normalizacyjny, Warszawa.

Projekt geotechniczny dla linii kolejowej nr 190 Goleszów - Cieszyn od km 33+200 do $\mathrm{km} 33+500,2020$. BAARS [materiały niepublikowane].

SOPO PIG-PIB, b.d., System Osłony Przeciwosuwiskowej, Państwowy Instytut Geologiczny - Państwowy Instytut Badawczy, https://geoportal.pgi.gov.pl/portal/page/ portal/SOPO/Wyszukaj3 [dostęp: 5.11.2021].

Stryczek S., 1999, Metody geoinżynieryjne modyfikujące właściwości fizyczno-mechaniczne ośrodka gruntowego oraz masywu skalnego, NTTB Nowoczesne Techniki i Technologie Bezwykopowe, nr 4, s. 74-79.

Stryczek S., Gonet A., Wiśniowski R., 2008, Geoinżynieryjne metody stabilizacji skarp i zboczy, Nowoczesne Budownictwo Inżynieryjne, nr 6, s. 78-81.

U.S. Department of the Interior Bureau of Reclamation, 2001, Penetration Testing, [w:] Engineering Geology Field Manual. Vol. 2, $2^{\text {nd }}$ ed., s. 351-408.

Wiłun Z., 2013, Zarys geotechniki, Wydawnictwa Komunikacji i Łączności, Warszawa. Wysokiński L., 2012, Metody prognozowania i zabezpieczania osuwisk [The Methods of Landslides Prediction and Their Protection]. [w:] Awarie budowlane: zapobieganie, diagnostyka, naprawy, rekonstrukcje: XXV konferencja naukowo-techniczna: Szczecin-Międzyzdroje, 24-27 maja 2011, Wydawnictwo Uczelniane ZUT, Szczecin, s. 291-320. 